Cynthia F. Xidieh · Henrique L. Lenzi

Vera Lucia G. Calich · Eva Burger

\title{
Influence of the genetic background on the pattern of lesions developed by resistant and susceptible mice infected with Paracoccidioides brasiliensis
}

Received: 1 October 1998

\begin{abstract}
To compare the sequential evolution of lesions developed by resistant (A/Sn) and susceptible (B10.A) mice to Paracoccidioides brasiliensis infection we inoculated a virulent isolate of the fungus and collected the pancreas/peripancreatic omentum monthly (from 1 to 6 months) post infection. After fixation, tissue sections were stained by conventional methods for light microscopy to investigate the cellular composition, the extracellular matrix (ECM) patterns and the morphology of the yeasts in the lesions. In both strains, the fungal lesions were localized mostly in the omentum; a few lesions in the pancreatic parenchyma were observed, mostly in B10.A mice. In both strains, macrophages and plasmocytes were the predominant cells in all lesions, followed by neutrophils (PMN) and macrophages transformed into giant and epithelioid cells. Remarkable differences were observed between resistant and susceptible mice, specially related to the ECM structure of the granulomatous lesions. In $\mathrm{A} / \mathrm{Sn}$ mice, from the 1st month on, the coexistence of two types of lesions was observed: one type showed a well-defined encapsulated nodule, constituted mainly of type I collagen. Neutrophils were abundant in areas of massive fungal destruction and few viable yeasts were observed. The other type showed residual characteristics, with sparse collagen deposits and presence of xantomatous-like macrophages, containing degenerated fungi. Such residual lesions predominated after the 2nd month and were the only type observed from the 4th month on, indicating the control of the infection. In B10.A mice, on
\end{abstract}

C. F. Xidieh · V. L. G. Calich · E. Burger $(\bowtie)$

Departamento de Imunologia, Instituto de Ciências Biomédicas, Universidade de São Paulo, Av. Prof. Lineu Prestes, 1730; 05508-900, São Paulo, SP, Brazil

e-mail: evburger@icb.usp.br,

Fax: + 55-11-818-7224

H. L. Lenzi

Departamento de Patologia, Instituto Oswaldo Cruz, Fundação Oswaldo Cruz, Fiocruz, Av. Brasil, 4365;

21045-900, Rio de Janeiro, RJ, Brazil the contrary, only one type of lesion was observed, showing less tendency to encapsulation and the formation of multiple small granulomatous foci, individualized by reticular type III collagen fibers. There were many plasmocytes in the periphery and large numbers of budding yeasts, with no evidence of fungal destruction. In the course of the infection the lesions progressively increased in number and size. Altogether, the comparative histopathological analysis demonstrates the influence of the genetic pattern of the host on the lesions developed by resistant and susceptible mice to P. brasiliensis infection.

Key words Paracoccidioidomycosis .

Histopathology · Granulomatous lesions · Inbred mouse strains

\section{Introduction}

Paracoccidioides brasiliensis is a fungus restricted to Latin America that causes one of the most prevalent human deep mycosis in this region [29]. Although the lungs are the organs primarily involved in paracoccidioidomycosis (PCM), dissemination to other tissues is commonly found, depending on aspects inherent to both the host (sex, age, nutritional state) and the infecting agent (virulence, size of the inoculum) [13]. PCM is a granulomatous disease and may present several clinical forms. The chronic form, the adult type of PCM, is the more frequent manifestation of the disease, in which several degrees of severity are observed [13]. Patients manifest depressed cellular immune responses that represent the main defense mechanism in PCM and high activation of the humoral compartment, to a greater or lesser extent, in accordance with the severity of the disease $[2,14,27]$.

In an isogenic murine model of PCM, Calich et al. [5] demonstrated differences in susceptibility to $P$. brasiliensis among inbred strains, related to their genetic pattern. A/Sn mice were resistant and B10.A mice sus- 
ceptible to intraperitoneal (i.p.) infection with the virulent isolate $\mathrm{Pb} 18$ of $P$. brasiliensis. The mean survival times were 283 and 124 days, respectively. However, a few susceptible mice survived until 200 days. Resistance to the fungus seemed to be controlled by a dominant autosomal gene [6], and the F1 hybrids of the breeding of $\mathrm{B} 10 . \mathrm{A}$ and $\mathrm{A} / \mathrm{Sn}$ mice were resistant to $P$. brasiliensis. After $\mathrm{Pb} 18$ i.p. infection, the analysis of several parameters indicated that resistant $\mathrm{A} / \mathrm{Sn}$ and susceptible B10.A mice developed disease with characteristics similar to those observed, respectively, in the localized and disseminated forms of chronic human PCM [7]. In resistant mice the infection was characterized by a high activation status of peritoneal macrophages and polymorphonuclear neutrophils (PMN), evidenced by the increase of hydrogen peroxide $\left(\mathrm{H}_{2} \mathrm{O}_{2}\right)$ production, and maintenance of superoxide anion $\left(\mathrm{O}_{2}^{-}\right)$production, low titers of total specific anti- $P$. brasiliensis antibodies, with preferential production of $\operatorname{IgG} 2 \mathrm{a}$ and $\mathrm{IgG} 3$ isotypes [8], absence of circulating P. brasiliensis antigens [15], and evident specific delayed-type hypersensitivity (DTH) [12] were also detected. On the other hand, in susceptible mice the macrophages and PMN produced low levels of $\mathrm{H}_{2} \mathrm{O}_{2}$ and $\mathrm{O}_{2}^{-}$, large quantities of antibodies (predominantly the $\operatorname{IgG} 2 \mathrm{~b}, \operatorname{IgG} 1$ and $\operatorname{IgA}$ isotypes) [8], increasing levels of antigenemia [15], and depression of specific DTH reactions to the fungus [12].

In this model, the involvement of the pancreas and the peripancreatic omentum, liver, spleen and lungs was quite frequent in both susceptible and resistant mice, as observed in anatomicopathogical studies [5]. These features were corroborated by the number of recovered viable $P$. brasiliensis: in B10.A the number of colonyforming units (CFU) from these organs was always higher than those observed in A/Sn mice from weeks 2 to 16 after $\mathrm{Pb} 18$ i.p. infection, when the lesions were present only in the susceptible B10.A mice [31]. Concerning the pancreas involvement, the infection of B10.A mice with $\mathrm{Pb} 18$ evoked a significant increase in their plasmatic amylase levels, a phenomenon not observed in the $\mathrm{A} / \mathrm{Sn}$ mice or in the $\mathrm{F} 1(\mathrm{~B} 10 . \mathrm{A} \times \mathrm{A} / \mathrm{Sn})$ hybrids, thus allowing the establishment of a positive correlation between the increase of amylase and the susceptibility of these animals to the fungus [34]. Differences in the pattern of histopathological lesions were also observed in these animals. In general, B10.A mice showed abundant and poorly organized granulomatous lesions rich in yeasts and plasmocytes, scattered in the tissue. In contrast, in $\mathrm{A} / \mathrm{Sn}$ mice only few granulomas were detected, presenting scarce fungal cells and plasmocytes [8].

In PCM, as in other infectious diseases (schistosomiasis, leprosy, tuberculosis and listeriosis), the formation of granulomas constitutes a delayed hypersensitivity reaction to antigens from the infecting agent. This reaction is greatly affected by cytokines influencing both the constituent cells and the extracellular matrix (ECM) fibers present in the lesions. Several cytokines [interleukin (IL)-1, IL-6, granulocyte-macrophage colony-stimulating factor] participate in the early inflam- matory reaction, promoting extravasation of leukocytes and expression of adhesion molecules by endothelial cells [22]. Some cytokines, such as transforming growth factor (TGF)- $\beta$, are strongly associated with the depressed cellular immune responses observed in granulomatous infectious diseases; its enhanced production by pulmonary macrophages and Langhans' giant cells in patients with active tuberculosis, counterbalance the macrophage stimulation by tumor necrosis factor- $\alpha$ and interferon (IFN)- $\gamma$ [32]. In the murine model of pulmonary PCM, it was observed that the depletion of IFN- $\gamma$ gives rise to an increase in the severity of the granulomatous lesions, in both resistant and susceptible mice, thus indicating the role of this cytokine in the development of this pathology [9]. The effect of ECM proteins on inflammatory cells was studied using human macrophages adhered to collagen 1 gel matrices, which showed an increased fungistatic activity against Histoplasma capsulatum yeasts [28]. Furthermore, the activity of proteolytic enzymes of the infecting agents may modulate the deposition of ECM fibers in the granuloma development [30].

In the present work the evolution of the granulomas in a relatively dense organ (pancreas) and in the loose connective tissue (peripancreatic omentum) was compared during the course of i.p. infection of susceptible and resistant mice with a virulent strain of $P$. brasiliensis. The study was performed analyzing the cellular composition and fibrotic architecture of the lesions, as well as the "in situ" effect of the fungus, taking into account the influence of the genetic pattern of the host on the establishment and development of the tissular reactions to $P$. brasiliensis.

\section{Material and methods}

\section{Animals}

Groups of 8- to 10-week-old males mice were used. For the experiments using resistant $\mathrm{A} / \mathrm{Sn}$ mice, groups of three to five animals were employed for each data point. For the experiments with susceptible B10.A mice, larger groups were formed to ensure that sufficient number of mice survived until the 6th month of infection. The mice were bred at the Departamento de Imunologia, Universidade de São Paulo animal facilities and fed with laboratory chow (Nuvilab CR-1, Nuvital) and acidified water ad libitum.

Fungus

The yeast forms of $P$. brasiliensis virulent isolate $\mathrm{Pb} 18$, cultivated in semi-solid Fava Netto's [11] medium at $35{ }^{\circ} \mathrm{C}$ were employed at the 7 th day in culture, which corresponds to the exponential phase of growth [19]. To prevent loss of virulence, every year a new sample of $\mathrm{Pb} 18$ is obtained after in vivo passage and stored in its micellar form in potato dextrose agar; $\mathrm{Pb} 18$ yeasts are maintained in sequential in vitro subcultivation for no longer than 3 months [20]. The yeast cells were washed in isotonic sterile saline and the fungal suspensions were employed at a concentration of $10 \times 10^{6}$ yeast cells $/ \mathrm{ml}$, adjusted using an hemocytometer. The viability of the fungal cells was evaluated using the vital dye Janus Green B [1], and was always higher than $80 \%$. 
Infection

The mice were inoculated i.p. using $5 \times 10^{6}$ fungal cells suspended in $0.5 \mathrm{ml}$ isotonic sterile saline solution. This dose was employed since previous results showed that it was an adequate inoculum to differentiate susceptible from resistant mice. Control groups of mice were inoculated with $0.5 \mathrm{ml}$ of isotonic sterile saline solution.

\section{Collection of tissue samples}

At 1-6 months after Pb18 infection mice were anesthetized with ethyl ether vapor, bled to allow better histological preparations and killed. The pancreas and lesser omenta (pancreaticosplenic and splenogastric regions) were removed and spread out in a piece of paper to preserve them extended. The organs were immediately fixed in Millonig formalin $\mathrm{pH} 7.2$ [10], and maintained at $4{ }^{\circ} \mathrm{C}$ until processed.

\section{Histopathological analysis}

For light microscopy, the fixed tissues were embedded in paraffin and $5-\mu \mathrm{m}$ sections were stained using the following methods: hematoxylin and eosin (H\&E) for a general overview; Grocott's methenamine-silver nitrate technique [17] for fungi identification and viability evaluation; Lennert's Giemsa [21], for cellular infiltrate characterization and Masson's trichrome [23], Gomori's silver reticulin [16] and picrosirius, with or without light polarization [18] for identification of collagen fibers.

Evaluation of the severity of lesions

The pathological alterations observed in each mouse were semiquantitatively expressed according to the lesions' severity: 0, ab- sence of lesions; 0.5 , very discrete; 1 , discrete; 1.5 , discrete to moderate; 2 , moderate; 2.5 , moderate to intense; and 3 , intense. This criterion was based on the number and size of granulomatous lesions, number of fungi with preserved morphology and the intensity of the inflammatory reaction. The number and size of the lesions were quantified employing a standardized reticulated objective (micrometer scale), allowing measurement of the area of each square. As the lesions showed irregular boundaries, their area was calculated summing the number of squares entirely filled by lesions with the half-number of squares partially occupied (approximate integral calculus).

\section{Results}

Preferential site of lesions

The lesions caused by $\mathrm{Pb} 18$ were preferentially found in the peripancreatic region, thus confirming previous observations that this loose connective tissue (epiploon) represents the target tissue after i.p. P. brasiliensis infections for both susceptible and resistant mice. The distribution and intensity of lesions found in the pancreas and peripancreatic omentum of $\mathrm{A} / \mathrm{Sn}$ and B10.A mice is shown in Fig. 1. Susceptible mice showed a more intense involvement of both epiploon and pancreas than the resistant ones. In the pancreas, from 2 months on, the majority of the susceptible animals had intensities scored 2 or higher, whereas almost all the resistant ones had lesions varying from 1 to 1.5 . This was even more marked for the epiploon, where from
Fig. 1 Individual data of fungal lesions in pancreas and epiploon of $\mathrm{A} / \mathrm{Sn}(\bigcirc)$ and B10.A (O) mice i.p. infected with $5 \times 10^{6}$ yeasts of Paracoccidioides brasiliensis isolate $\mathrm{Pb} 18$. The severity of lesions was semiquantitatively expressed as: 0 absence of lesions, 0.5 very discrete lesions, 1 discrete, 1.5 discrete to moderate, 2 moderate, 2.5 moderate to intense, and 3 intense. This criterion was based on the number and size of granulomatous lesions, number of fungi and the intensity of the inflammatory reaction
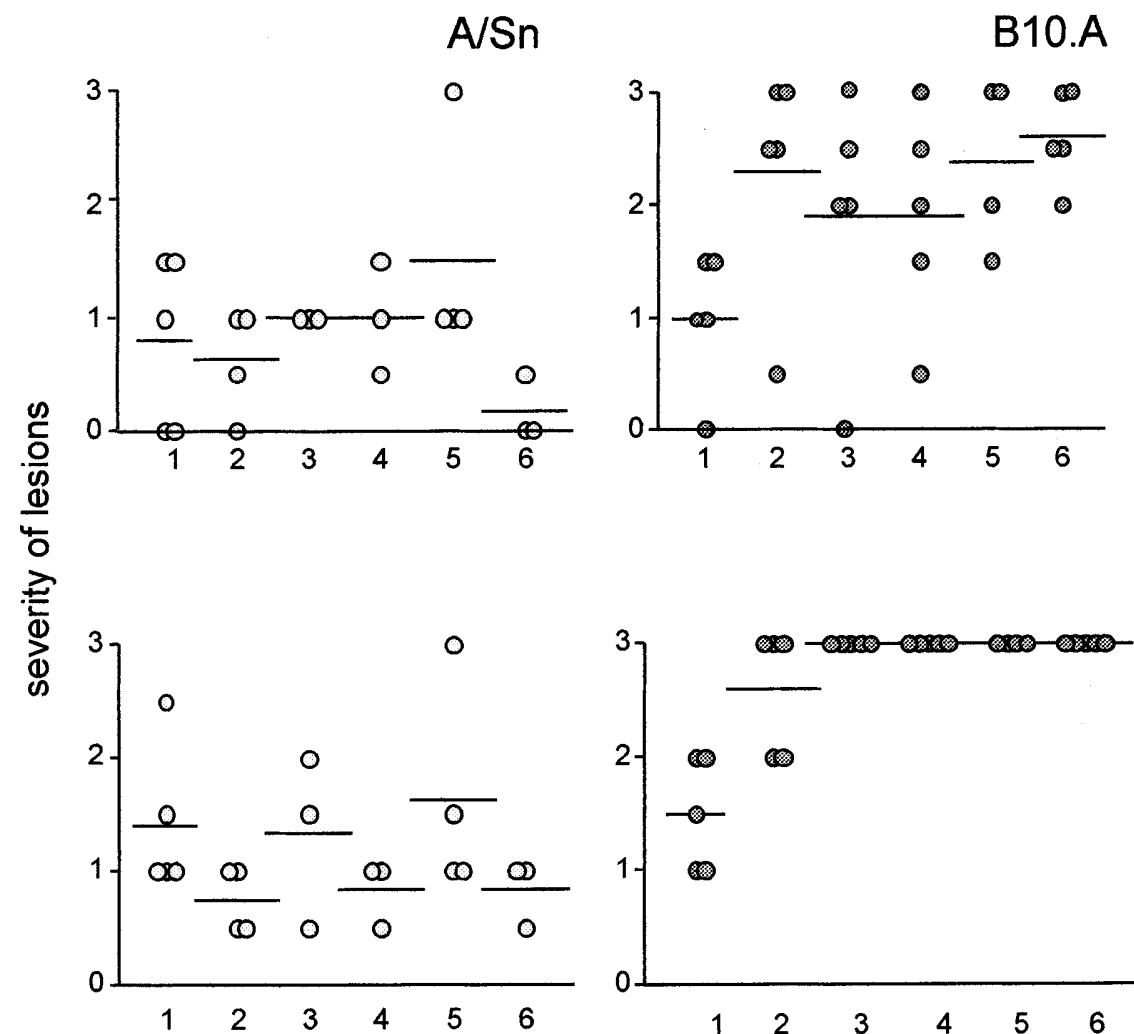

pancreas

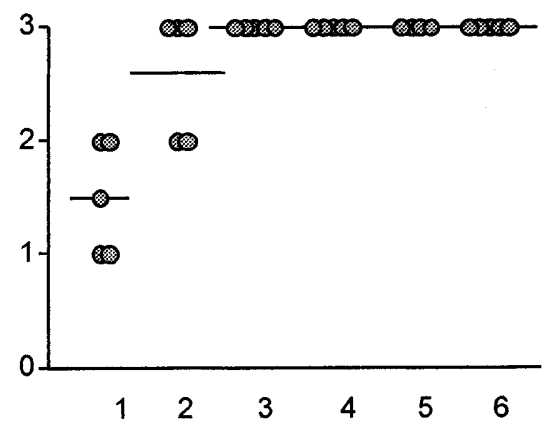

epiploon

months after infection 
3 months on all susceptible mice scored 3 , whereas only one mouse of the resistant group did so. The severity of the lesions found in the epiploon was higher than that found in the pancreas for both mouse strains. Recent, unpublished data of CFU per gram of pancreas and epiploon show a marked difference in the numbers of viable $P$. brasiliensis recovered from these organs. Already at 7 and 15 days after infection, a growth of 1406 and $1415 \mathrm{CFU} / \mathrm{g}$ tissue, respectively, was found in B10.A mice, in contrast to 0 and $71 \mathrm{CFU} / \mathrm{g}$ recovered from $\mathrm{A} / \mathrm{Sn}$ mice. This difference in the number of viable yeast cells recovered from the two mouse strains was also observed in the later phases of the infection [31].

\section{Omentum involvement}

Histologically, the peripancreatic omentum presented fungal lesions in all the mice analyzed. In this region different patterns of granulomas were detected in resistant and susceptible hosts.

In resistant $\mathrm{A} / \mathrm{Sn}$ mice two types of lesions could be distinguished. One type was an encapsulated, active lesion with deposition of ECM proteins, forming a dense fibrotic capsule, as shown in Fig. 2A, mainly composed by type I collagen fibers identified by picrosirius stain with polarized light (red/yellow fibers, Fig. 2B). In this type of lesion, foci of PMN were quite frequent, surrounding P. brasiliensis yeasts (Fig. 2C). We could also identify some $P$. brasiliensis yeasts with preserved morphology localized in the central area of the granulomas (Fig. 2D, left), free fungal debris in areas of neutrophil concentration (Fig. 2D, central area) and intracellular fungal debris in the external cellular layer of the lesion (Fig. 2D, right), in sections stained by Grocott's method. These types of granulomas were especially detected at 1 month post infection. The other type of lesion found in resistant mice was a non-capsulated, loose nodule with residual characteristics. These lesions were permeated by sparse collagen fibers, stained red by the picrosirius method (Fig. 2E); the same residual lesion is shown in Fig. 2F using polarized light, to give a better identification of the small amount of collagen fibers (stained in green/yellow), concentrated in the central area of the lesions. This type of lesion was mainly composed of xantomatous-like macrophages, denominated "pseudoxantomatous" macrophages (Fig. 2G). These cells containing degenerated fungi were evidenced by Grocott's stain (Fig. 2H). This type of lesion was already present at 1 month post-infection, simultaneously with the active lesions, became predominant from 2 months on, and was the unique kind of lesion present from 4 month onwards.

In susceptible B10.A mice only one type of lesion was observed in the course of $P$. brasiliensis infection, showing less tendency to define a capsule, and with little or absent type I collagen deposition, as showed in the Fig. 3A using picrosirius staining. These lesions could be defined as a nodule composed of multiple granuloma- tous foci, each surrounded by a thin layer of reticular collagen fibers, specially of type III, stained yellow/green by polarized light on picrosirius staining (Fig. 3B). The multiple granulomatous foci are shown in Fig. 3C, each of which was composed of macrophages and fungi. In the periphery of the lesion, large numbers of plasmocytes were always observed (Fig. 3D). In these lesions Langhans' giant cells, with many nuclei, were quite common, especially in the chronic phases after 4 months post-infection (Fig. 3E). Yeasts of P. brasiliensis with preserved morphology were found in large numbers, with abundant budding and insignificant levels of fungal destruction (Fig. 3F). The architecture of the multifocal granulomas was not altered during the course of the infection; however, with the chronicity of the disease, the granulomas became more expanded and reflected severe disease. In fact, in this experimental model after 5 months of infection the majority of the infected B10.A mice had died. Indeed, most deaths for this mouse strain occurred between 50 and 180 days, a much shorter time when compared to the resistant $\mathrm{A} / \mathrm{Sn}$ mice, which died between 90 and 600 days post infection [8].

\section{Pancreatic involvement}

The histopathological analysis of the pancreas allowed us to conclude that from 2 months post infection an important impairment of the pancreatic parenchyma occurred in susceptible B10.A mice. In most mice of this strain, the lesions varied from those of moderate to those of severe intensity, whereas in the resistant $\mathrm{A} / \mathrm{Sn}$ mice almost all lesions were discrete (only one A/Sn mouse had a severe pancreatic lesion, 5 months post-infection). Even in B10.A mice, the pancreatic tissue was mostly preserved, with almost all lesions being localized in the external lobules, which were in contact with the pseudocapsule of the pancreas. Figure $3 \mathrm{G}$ shows a discrete inflammatory infiltrate, in addition to a small granuloma, involving a few pancreatic acinar cells in $\mathrm{A} / \mathrm{Sn}$ mice 3 months after Pb18 infection. In B10.A mice, the inflammatory reaction to the presence of $P$. brasiliensis was more intense, with destruction of several pancreatic lobules, preserving some atrophied ducts and cells as shown in Fig. 3H.

Fig. 2 A Active encapsulated lesion in peripancreatic omentum, with collagen fibers encircling inflammatory and fungal cells; picrosirius stain. B The same section, showing the collagen capsule (red/yellow fibers) of the lesion, under polarized light microscopy. C Foci of neutrophils surrounding $\mathrm{Pb} 18$ yeasts; H\&E. D Pb18 in a granulomatous lesion: some viable yeasts (left), fungal debris (center), degenerated fungi within macrophages (right); Grocott staining. E Residual lesion permeated by sparse collagen fibers; picrosirius staining. F Detail of the thin collagen structure of this lesion (yellow fibers) observed with polarized light. G Pseudoxantomatous macrophages in residual lesion; Masson's trichrome. H Degenerated yeasts of Pb18, within pseudoxantomatous macrophages in residual lesion; Grocott's staining. A/Sn mice, 1 month (A-D) and 4 months $(\mathbf{E}-\mathbf{H})$ after i.p. infection with $5 \times 10^{6}$ yeasts of Pb18. A, $\mathbf{E} \times 250 ; \mathbf{B}, \mathbf{F} \times 100 ; \mathbf{C}, \mathbf{D}$ $\times 125 ; \mathbf{G}, \mathbf{H} \times 500$ 
A

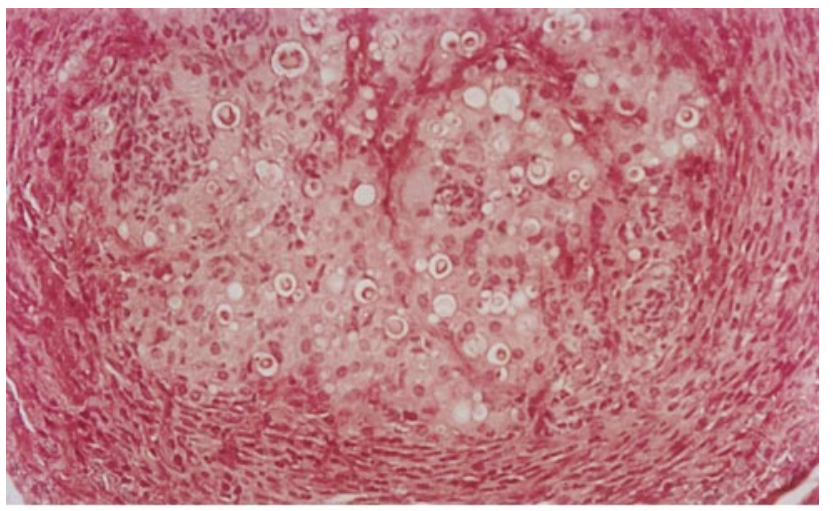

C

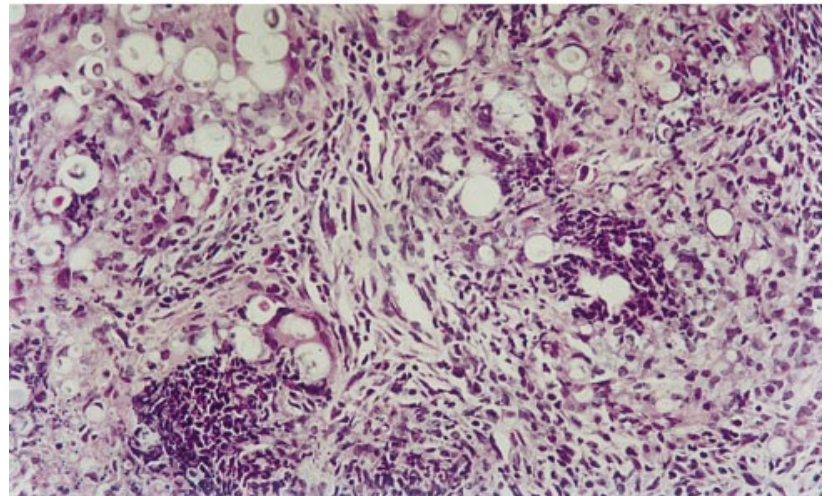

E

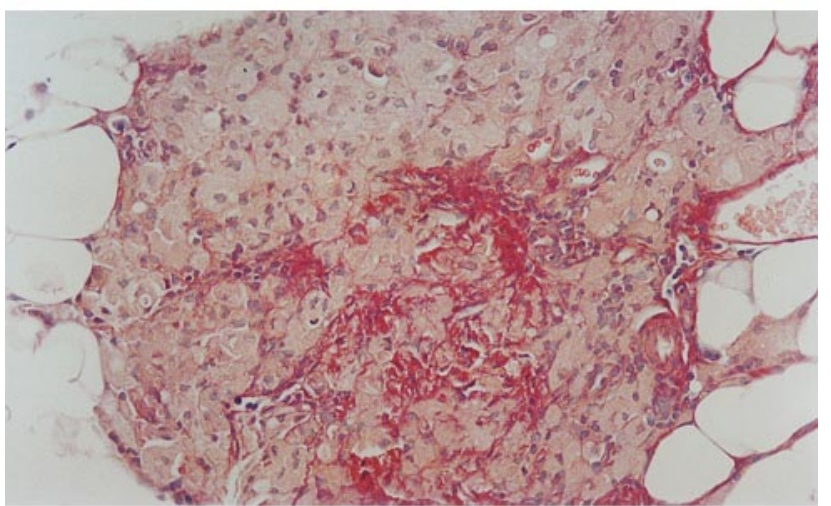

G

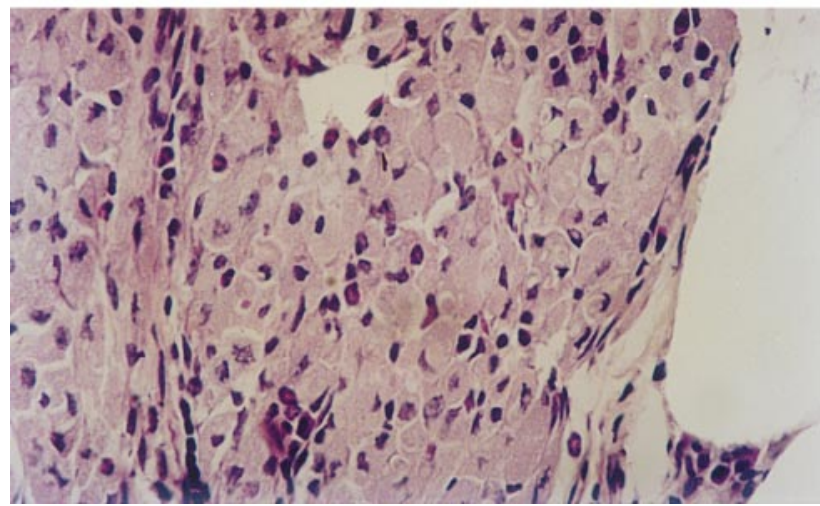

Comparison of paracoccidioidomycotic lesions evolution in resistant and susceptible

The characteristic patterns of lesions developed by each mouse strain are already well established by
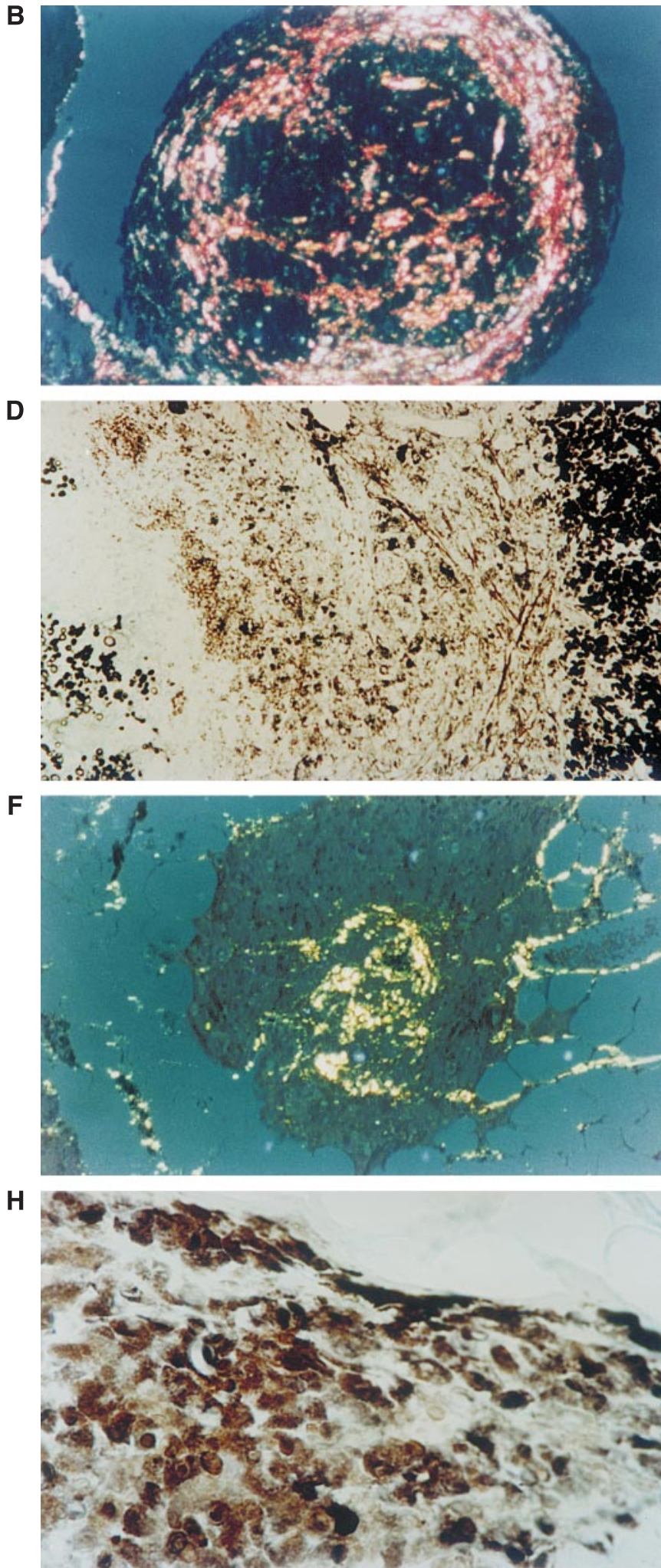

3 months post infection. The striking differences in the number, type and size of the lesions observed in $\mathrm{A} / \mathrm{Sn}$ and B10.A mice during these 3 months are indicated in Table 1. After 2 months the infection is under control in mice of the resistant strain, as shown by the 
A
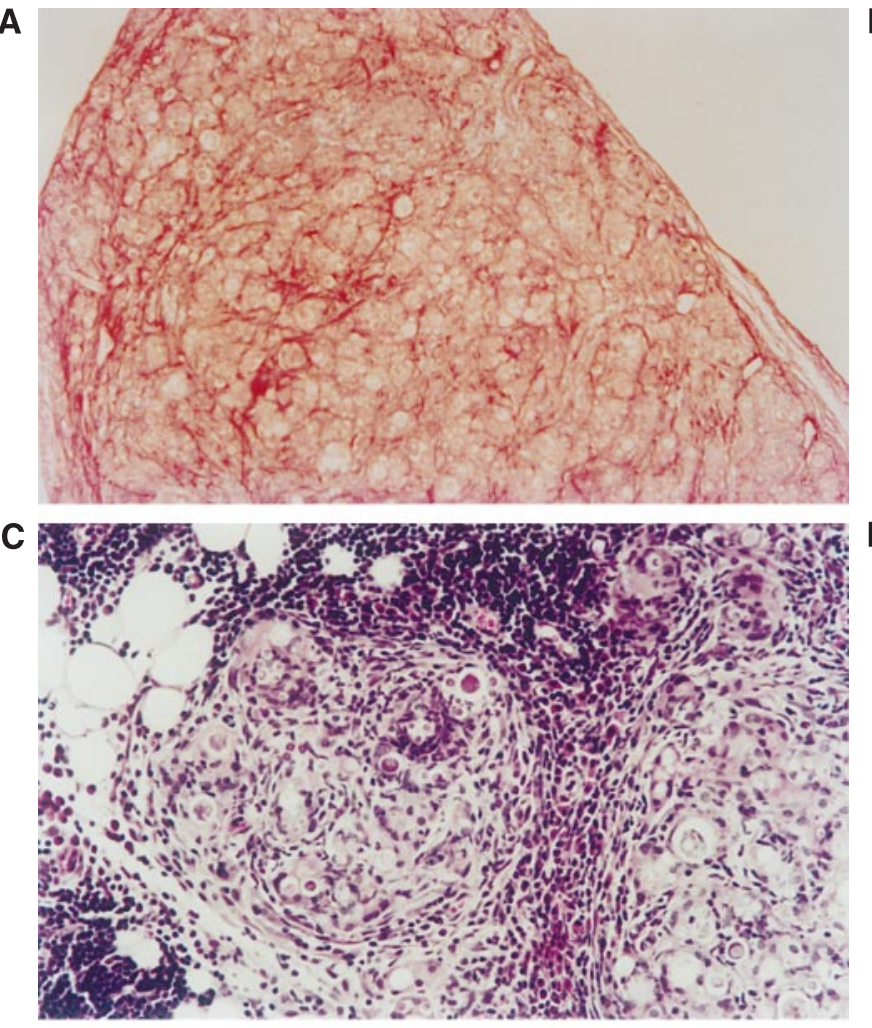

E

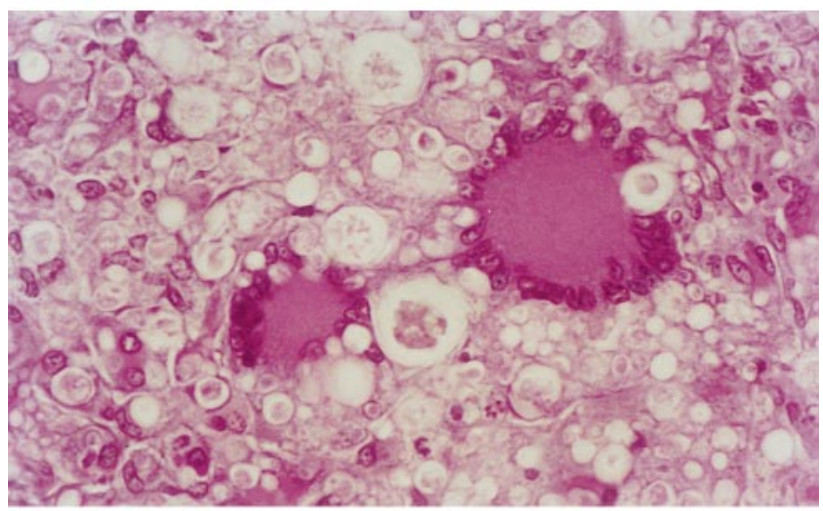

G

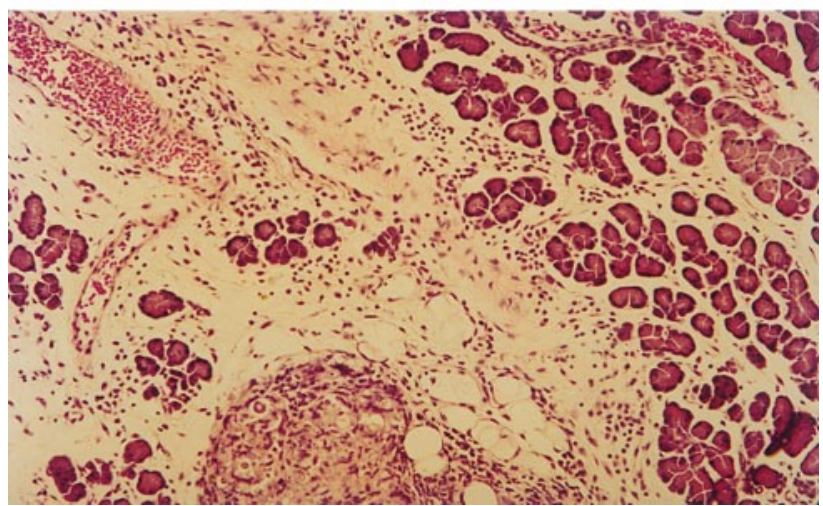

increasing percentage of residual lesions in which most of the fungi were degenerated. On the other hand all the lesions found in mice of the susceptible strain were active, containing fungi with well preserved morphology. Moreover, the mean size of the granulomas of
B
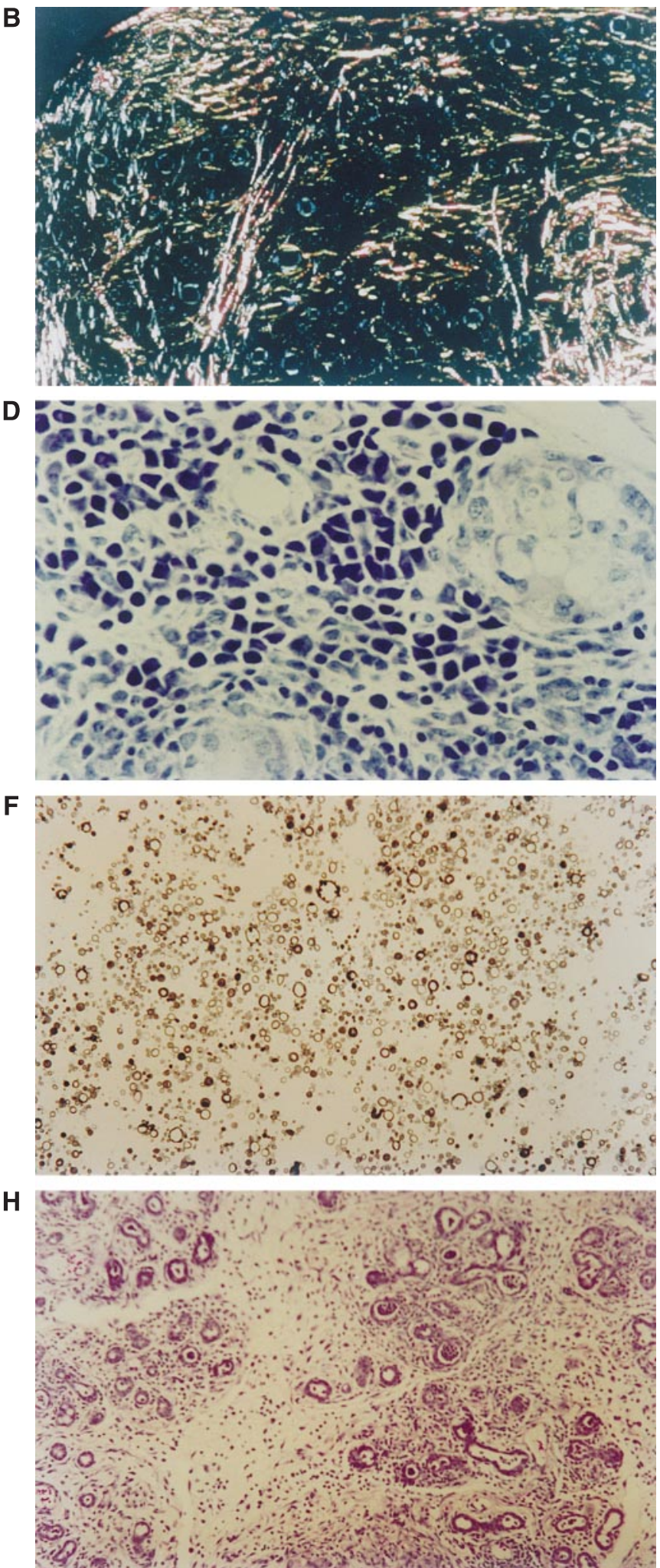

B10.A mice at 3 month post infection is strikingly larger when compared to those found at the previous time points analyzed; in the subsequent months the sizes of the lesions tended to stabilize (data not shown). 
Fig. 3 A Nodular non-capsulated peripancreatic lesion permeated by delicate collagen fibers; picrosirius staining. B Detail of the ECM proteins in a non-capsulated lesion showing collagen fibers (yellow/ green/red fibers) and P. brasiliensis yeasts (green spherical structures); picrosirius staining plus polarized light. C Granulomatous foci surrounded by ECM compounds and mononuclear cells; H\&E. D Plasmocytes in the periphery of the granulomatous foci; Giemsa stain. E Two Langhans' giant cells with many nuclei and PB18 yeasts; $\mathrm{H} \& \mathrm{E}$. F Pb18 yeasts in granulomatous foci; Grocott's staining. G Discrete pancreatic lesion involving few peripheral pancreatic lobules; H\&E. H Severe pancreatic lesion with destruction of many lobules; H\&E (ECM extracellular matrix). A, B, G, H At 2 months after i.p. infection with $5 \times 10^{6}$ yeasts of Pb18; C, D, E At 1 month after infection; $\mathbf{F}$ At 4 months after infection in mouse strain B10.A $(\mathbf{A}-\mathbf{F}, \mathbf{H})$ and $\mathrm{A} / \mathrm{Sn}(\mathbf{G}) . \mathbf{A}, \mathbf{C}, \mathbf{E}-\mathbf{H} \times 125 ; \mathbf{B} \times 200 ; \mathbf{D} \times 500$

\section{Discussion}

The observed meager involvement of the pancreatic tissue in experimental murine PCM suggests that these lesions were established by contiguity from those present in the peripancreatic omentum. The present results, as well as the previous ones obtained in this model, show that the fungal lesions in abdominal organs were frequently restricted to their periphery, at their capsules. The connective tissue of the omenta drained the fungal inoculum, thus representing the target organ in the paracoccidioidomycotic i.p. infection. Our present results show that the pancreatic tissue of mice is mostly preserved after $\mathrm{Pb} 18$ i.p. infection, even in the susceptible B10.A strain. In a previous study of the kinetics of plasma amylase, marked differences between resistant and susceptible mice were demonstrated at 1 month post-infection, with an increase in the levels of this enzyme only being observed in susceptible B10.A [34]. The present histological findings are in accordance with these data, indicating that the early alteration detected in the exocrine function of this organ is transitory and reversible. The arrangement of the paracoccidioidomycotic lesions is very different in resistant and in susceptible mice. It is known that the deposition of the various components of the ECM is dependent on several factors. For instance, TGF- $\beta$ promotes the recruiting, proliferation and activation of fibroblasts as well as the syn- thesis of collagen by these cells [33]. The presence of cytokines in the lesions has not yet been an object of study in experimental PCM; however, it has been shown that the production of IFN- $\gamma$ by total lymph nodes cells is higher in resistant mice [4], and that of TGF- $\beta$ tends to be higher in susceptible mice in an early phase after fungal i.p. infection (24 h) [25].

In resistant $\mathrm{A} / \mathrm{Sn}$ mice we observed a massive lysis of $P$. brasiliensis yeasts in situ, denoted by the large amount of free and intracellular fungal detritus found in the granulomas; in contrast, in the susceptible B10.A strain the fungus survived, maintaining its morphology and actively budding, as detected progressively at later phases of the infection.

The overall cellular reaction developed by resistant mice culminated in the lysis of $P$. brasiliensis, whereas the one developed by susceptible mice allowed the survival of the fungi in the lesions. This shows that the cells involved are in a different state of activation. Indeed, it has previously been shown in the murine model of PCM that at the site of subcutaneous inoculation of P. brasiliensis, at 15 days post infection, the PMN from resistant mice are activated, whereas those from susceptible mice are not, as evaluated by the production of $\mathrm{H}_{2} \mathrm{O}_{2}$ and $\mathrm{O}_{2}^{-}$. This activation was parallel to the fungicidal activity, so that the PMN of resistant mice killed P. brasiliensis in vitro and those of B10.A did not [24]. These data suggest that different cytokines and/or cell subsets may be present at the site of the lesion. Calich et al. [4] have recently demonstrated that there is preferential production of IFN- $\gamma$ and IL-2, derived from type $1 \mathrm{~T}$ lymphocytes, during the entire course of infection in resistant mice but only a negligible amount of IFN $-\gamma$ at the initial phases of the infection and no IL-2 in susceptible mice. These type 1 cytokines are important in stimulating phagocytosis by macrophages and in enhancing their antimicrobial activity [26].

From our present observations, there is a very strong indication that the PMN are responsible for the death of the fungi. The time-courses for presence of PMN and that for lysed yeasts are similar; moreover, the physical proximity of the fungi and the PMN strongly suggests that the role of this cell population is to effectively control the initial fungal load, by lysing $P$. brasiliensis. The macro-

Table 1 Evolution of pancreatic and peripancreatic lesions during the first 3 months after i.p. inoculation of resistant and susceptible mice with $5 \times 10^{6}$ yeast forms of Paracoccidioides brasiliensis

\begin{tabular}{|c|c|c|c|c|c|c|}
\hline \multirow{2}{*}{$\begin{array}{l}\text { Mouse strain } \\
\text { Months post-infection }\end{array}$} & \multicolumn{3}{|c|}{ Resistant (A/Sn) } & \multicolumn{3}{|c|}{ Susceptible (B10.A) } \\
\hline & 1 & 2 & 3 & 1 & 2 & 3 \\
\hline Number of lesions ${ }^{\mathrm{a}}$ & $39(5)$ & $20(4)$ & $19(3)$ & $65(5)$ & $119(5)$ & $112(5)$ \\
\hline$\%$ of active lesions ${ }^{b}$ & 92.3 & 40 & 5.3 & 100 & 100 & 100 \\
\hline$\%$ of residual lesions ${ }^{b}$ & 7.7 & 60 & 94.7 & 0 & 0 & 0 \\
\hline Mean size $\left(\mu \mathrm{m}^{2}\right)^{\mathrm{c}}$ & 5166 & 1412 & 2901 & 2627 & 9285 & 27,009 \\
\hline
\end{tabular}

\footnotetext{
${ }^{\text {a }}$ Sum of lesions found in pancreas and epiploon, with the number

${ }^{\mathrm{c}}$ Mean area of the lesions, calculated as described in Material and
} of analyzed mice in each time post-infection in parentheses ${ }^{\mathrm{b}}$ Characteristics of the lesions, active or residual, as defined in Results

\section{methods}


phages, on the other hand, are most likely to be acting as scavenger cells, removing cellular and fungal debris originating by the action of PMN, in spite of the previous demonstration that macrophages from resistant mice are more activated that those from susceptible ones, as evaluated by $\mathrm{H}_{2} \mathrm{O}_{2}$ production, spreading activity and maintained expression of class II antigens [8]. The data reported here indicate distinct roles for different phagocytic cell populations in the evolution of the paracoccidioidomycotic granulomatous lesions. The PMN, present in large numbers in A/Sn mice, seem to be able to kill $P$. brasiliensis, whereas the macrophages from resistant mice, specially in residual lesions, have a foamy appearance resulting from fungi debris in their interior. This association between degenerated fungi and presence of PMN and pseudoxantomatous macrophages has already been described by Burger et al. [3], studying other model of susceptibility and resistance in athymic and euthymic BALB/c mice i.p. infected with $P$. brasiliensis.

The ECM deposition pattern on the lesions differed between the resistant and susceptible strains. In $\mathrm{A} / \mathrm{Sn}$ mice the active granulomas containing viable yeasts were encapsulated, showed large quantities of dense collagen fibers, probably collagen type I, identified by the picrosirius stain plus polarized light as red fibers. In B10.A mice, the granulomatous lesions were sustained by a thin fibrotic structure which do not define a capsule, composed mostly of reticular collagen type III, in close contact with yeasts and macrophages. In the residual lesions of resistant A/Sn mice, with no viable $P$. brasiliensis yeasts, the ECM fibers were almost absent. Thus, the interaction between the antigens of the pathogen and host defenses result in a differential activation of the ECM.

In resistant $\mathrm{A} / \mathrm{Sn}$ mice the cellular reaction is effective, promoting a marked pathogen destruction by activated neutrophils and the delimitation of the area of injury by ECM components. In susceptible B10.A mice, on the contrary, the fungal multiplication is not controlled, indicating inefficient activation of cellular mechanisms, thus permitting the thriving of $P$. brasiliensis and the impairment of its seclusion by ECM deposition. Therefore, the present work strongly suggests that the host's genetic pattern determines differences in the outcome of tissular reactions to P. brasiliensis i.p. infection.

Acknowledgements C. F. Xidieh was recipient of Ph.D. fellowship 141557/95-8 from Conselho Nacional de Pesquisas (CNPq). This work was supported by grants from Fundação de Amparo à Pesquisa do Estado de São Paulo (FAPESP) no. 96/05335-3 and CNPq no. 52452096/8.

\section{References}

1. Berliner MD, Reca ME (1966) Vital staining of Histoplasma capsulatum with Janus Green B. Sabouraudia 5:26-29

2. Biangioni A, Souza MJ, Chamma LG, Mendes RP, Marques SA, Mota NGS, Franco M (1984) Serology of paracoccidioidomycosis. II. Correlation between class-specific an- tibodies and clinical forms of the disease. Trans $\mathrm{R}$ Soc Trop Med Hyg 78:617-621

3. Burger E, Miyaji M, Sano A, Calich VLG, Nishimura K, Lenzi HL (1996) Histopathology of paracoccidioidomycotic infection in athymic and euthymic mice: a sequential study. Am J Trop Med Hyg 55:235-242

4. Calich VLG, Kashino SS (1998) Cytokines produced by susceptible and resistant mice in the course of paracoccidioidomycosis. Braz J Med Biol Res 31:615-623

5. Calich VLG, Singer-Vermes LM, Siqueira AM, Burger E (1985) Susceptibility and resistance of inbred mice to Paracoccidioides brasiliensis. Br J Exp Pathol 66:585-599

6. Calich VLG, Burger E, Kashino SS, Fazioli RA, Singer-Vermes LM (1987) Resistance to Paracoccidioides brasiliensis in mice is controlled by a single dominant autosomal gene. Infect Immun 55:1919-1923

7. Calich VLG, Fazioli RA, Teixeira HC, Russo M, Singer-Vermes LM, Burger E, Vaz CAC (1988) Mechanisms of hostresistance to Paracoccidioides brasiliensis. In: Torres-Rodrigues JM (ed) Proceedings of the Xth Congress of the International Society for Human and Animal Mycology. Prous Scientific, Barcelona, pp 154-159

8. Calich VLG, Singer-Vermes LM, Russo M, Vaz CAC, Burger $\mathrm{E}$ (1994) Immunogenetics in paracoccidioidomycosis. In: Franco MF, Lacaz CS, Restrepo A, Del Negro G (eds) Paracoccidioidomycosis. CRC Press, Boca Raton, pp 151-173

9. Cano LE, Kashino SS, Arruda C, André D, Xidieh CF, SingerVermes LM, Vaz CAC, Burger E, Calich VLG (1998) Protective role of gamma interferon in experimental pulmonary paracoccidioidomycosis. Infect Immun 66:800-806

10. Carson FL, Martin JH, Lynn JA (1973) Formalin fixation for electron microscopy: a re-evaluation. Am J Clin Pathol 59:365373

11. Fava Netto C (1961) Contribuição para o estudo imunológico da blastomicose de Lutz. Rev Instit Adolfo Lutz 21:99-194

12. Fazioli RA, Kashino SS, Calich VLG (1994) Delayed-type hypersensitivity response in an isogenic murine model of paracoccidioidomycosis. Mycopathologia 126:137-146

13. Franco M, Montenegro MR, Mendes RP, Dillon NL, Mota NGS (1987) Natural history of paracoccidioidomycosis: correlation with a recently proposed classification of its clinical forms. Rev Soc Bras Med Trop 20:129-132

14. Franco MF, Mendes RP, Morcardi-Bacchi M, Rezkallah-Iwasso MT, Montenegro MR (1989) Paracoccidioidomycosis. Baillieres Clin Trop Med Commun Dis 4:185-200

15. Garcia NM, Singer-Vermes LM, Calich VLG, Burger E (1997) Antigenemia in the isogenic murine model of paracoccidioidomycosis. In: Proceedings of the 13th Congress of the International Society for Human and Animal Mycology, Salsomaggiore, Italy. ISHAM and University of Parma, Parma, abstr. no. P419

16. Gomori G (1950) A rapid one-step trichrome stain. Am J Clin Pathol 20:661-664

17. Grocott RG (1955) A stain for fungi in tissue sections and smears, using Gomori's methenamine-silver nitrate technic. Am J Clin Pathol 25:975-979

18. Junqueira LCU, Bignolas G, Brentani RR (1979) Picrosirius staining plus polarization microscopy, a specific method for collagen detection in tissue sections. Histochem J 11:447455

19. Kashino SS, Calich VLG, Burger E, Singer-Vermes LM (1985) In vivo and in vitro characteristics of six Paracoccidioides brasiliensis strains. Mycopathologia 92:173-178

20. Kashino SS, Singer-Vermes LM, Calich VLG, Burger E (1990) Alterations in the pathogenicity of one Paracoccidioides brasiliensis isolate do not correlate with its in vitro growth. Mycopathologia 111:173-180

21. Lennert K (1978) Malignant lymphomas other than Hodgkin's disease, 1st edn. Springer, Berlin Heidelberg New York, p 77

22. Mantovani A, Bussolino F, Introna M (1997) Cytokine regulation of endothelial cell function: from molecular level to the bedside. Immunol Today 18:231-240 
23. Masson PJ (1929) Trichrome stainings and their preliminary technique. J Tech Methods 12:75-90

24. Meloni-Bruneri LH, Campa A, Abdalla DSP, Calich VLG, Lenzi HL, Burger E (1996) Neutrophil oxidative metabolism and killing of $P$. brasiliensis after air pouch mice infection of susceptible and resistant mice. J Leukoc Biol 59:526-533

25. Moraes SMD, Calich VLG, Burger E (1997) Production of TGF- $\beta$ in an isogenic murine model of paracoccidioidomycosis. II. Studies with a highly virulent isolate. In: Proceedings of the 13th Congress of the International Society for Human and Animal Mycology, Salsomaggiore, Italy. ISHAM and University of Parma, Parma, abstr. no. P420

26. Mosmann TR, Coffman RL (1989) Th1 and Th2 cells: different patterns of lymphokyne secretion lead to different functional properties. Annu Rev Immunol 7:145-173

27. Mota NGS, Rezkallah-Iwasso MT, Peraçoli MTS, Audi RC, Mendes RP, Marcondes J, Marques SA, Dillon NL, Franco MF (1985) Correlation between cell-mediated immunity and clinical forms of paracoccidioidomycosis. Trans R Soc Trop Med Hyg 79:765

28. Newman SL, Gootee L, Kidd C, Ciraolo G, Morris R (1997) Activation of human macrophage fungistatic activity against
Histoplasma capsulatum upon adherence to type I collagen matrices. J Immunol 158:1779-1786

29. Restrepo A (1985) The ecology of P. brasiliensis: a puzzle still unsolved. J Med Vet Mycol 23:323-334

30. Rhoads ML, Fetterer RH (1997) Extracellular matrix: a tool for defining the extracorporeal function of parasite proteases. Parasitol Today 13:119-122

31. Singer-Vermes LM, Caldeira CB, Burger E, Calich VLG (1993) Experimental murine paracoccidioidomycosis: relationship among dissemination of the infection, humoral and cellular immune responses. Clin Exp Immunol 94:75-79

32. Toossi Z, Gogate $P$, Shiratsuchi H, Young $T$, Ellner JJ (1995) Enhanced production of TGF- $\beta$ by blood monocytes from patients with active tuberculosis and presence of TGF- $\beta$ in tuberculous granulomatous lung lesions. J Immunol $154: 465-473$

33. Wahl SM (1992) Transforming growth factor beta in inflammation: a cause and a cure. J Clin Immunol 12:61-74

34. Xidieh CF, Singer-Vermes LM, Calich VLG, Burger E (1994) Plasmatic amylase levels as parameters of disease intensity in an isogenic murine model of paracoccidioidomycosis. J Med Vet Mycol 32:37-45 